\title{
Strategi Kebijakan Pembangunan Berkelanjutan Wisata Pantai Di Kawasan Lombok Timur
}

\author{
Novia Suhastini \\ noviasuhastini@uinmataram.ac.id
}

\begin{abstract}
The development of tourism which has recently been highlighted by the mass media in Indonesia with the government's program in tourism development as an addition to foreign exchange from the non-oil and gas sector. The tourism development program, which has been launched since 1988, is expected to attract the presence of foreign tourists and domestic tourists, which in turn will benefit the country's financial income. The exoticism of the beach has become one of the tourist strengths of East Lombok Regency. Along the coast in the south eastern Lombok region, lined with very attractive beaches. The development of attractions that are constrained by infrastructure, especially the problem is the lack of electricity and roads for access to locations are inadequate. The problem solving, it takes a policy of analyzing tourism policies in East Lombok Regency must pay attention; policy alternaitf, Policy implementation and policy evaluation.

[Pengembangan pariwisata yang akhir-akhir ini banyak disoroti oleh media massa di Indonesia adalah sejalan dengan program pemerintah dalam pengembangan pariwisata sebagai penambah devisa negara diluar sektor nonmigas. Program pengembangan pariwisata yang dicanangkan sejak tahun 1988, diharapkan menarik kehadiran wisatawan mancanegara dan wisatawan nusantara yang pada akhirnya akan mendatangkan keuntungan bagi pemasukan keuangan Negara. Eksotisme alam pantai menjadi salah satu andalan wisata Kabupaten Lombok Timur (Lotim). Terbilang di sepanjang pantai di kawasan Lombok timur bagian selatan, berjejer pantai-pantai yang sangat menarik. Hanya saja, pengembangan obyek wisata itu terkendala infrastruktur, terlebih yang menjadi permasalahan adalah belum meratanya listrik dan jalan raya untuk akses ke lokasi belum memadai. Dalam penyelesaian permasalahan, dibutuhkan sebuah kebijakan pem analisis kebijakan pariwisata di Kabupaten Lombok Timur harus memperhatikan; alternaitf kebijakan, Implementasi kebijakan dan evaluasi kebijakan.]
\end{abstract}

\section{Kata Kunci: Strategi Kebijakan, Pembangunan Berkelanjutan}

\section{A. Pendahuluan}

Pariwisata berasal dari bahasa sanskerta yang terdiri dari dua suku kata yaitu "Pari" dan "Wisata", Pari berarti berulang-ulang atau berkali-kali, sedangkan Wisata berarti perjalanan atau bepergian, jadi pariwisata berarti perjalanan yang 
dilakukan berulang-ulang atau berkali-kali ${ }^{1}$. Proses bepergian ini dapat menyebabkan terjadinya interaksi, dan hubungan-hubungan, kepuasan, kenikmatan dan lain-lain diantara sesama, pribadi atau antar kelompok².

Pengembangan pariwisata yang akhir-akhir ini banyak disoroti oleh media massa di Indonesia adalah sejalan dengan program pemerintah dalam menggalakkan pariwisata sebagai penambah devisa negara diluar sektor nonmigas. Program pengembangan pariwisata yang dicanangkan sejak tahun 1988, diharapkan menarik kehadiran wisatawan mancanegara dan wisatawan nusantara yang pada akhirnya akan mendatangkan keuntungan bagi pemasukan keuangan Negara3, peranan pariwisata dalam pembangunan Negara pada garis besarnya berintikan tiga segi yakni segi ekonomis (sumber devisa, pajak-pajak), segi sosial (penciptaan lapangan kerja), dan segi kebudayaan (memperkenalkan kebudayaan kita pada wisatawan)4. Pembangunan nasional Indonesia bertujuan mewujudkan suatu masyarakat adil, makmur merata secara material spiritual berdasarkan Pancasila dan UUD 1945 sebagai suatu proses perubahan berkesinambungan, terjadi secara terus menerus yang melibatkan semua unsur di dalamnya, yaitu pemerintah pusat ataupun daerah dan masyarakat serta dunia usaha. Kebijakan diperlukan bagi suatu organisasi yang di sebut dengan Negara, ketika Negara itu terbentuk maka Negara bersangkutan melalui konstitusi mengatur tata kehidupan pemerintah, Negara dan Publik5.

${ }^{1}$ Andayani S, dkk. Jurnal Rekayasa Sipil (Pengembangan Kawasan Wisata Balekambang Kabupaten Malang), Volume 6, No. 2-2012 ISSN 1978-5658.

2 Irianto. Jurnal Bisnis dan Kewirausahaan (Dampak Pariwisata Terhadap Kehidupan Sosial dan Ekonomi Masyarakat di Gili Trawanagna Kecamatan Pemenang Kabupaten Lombok Utara). Vol.7 No.3 November 2011.

3 Prasetyo P, Jurnal IImu Pemerintahan, (Strategi Dinas Kebudayaan Pemuda dan Olahraga Dalam Pengembangan Potensi Objek Wisata Kota Tarakan), 2013, $1(1): 151-164$.

${ }^{4}$ Wiryawan I.W.G. Jurnal Advokasi (Paradoks Kebijakan Industrialisasi Pariwisata Dengan Perlindungan Terhadap Upah Pekerja di Bidang Kepariwisataan di Provinsi Bali). Vol.3 No.1 April 2013.

${ }^{5}$ Suratmi, Santosa S., Manajemen Bisnis Syariah (Strategi Pemerintah Kota Surakarta dalam Melakukan City Branding Sebagai Kota Budaya). No. 2/Th.VI/ Februari 2013. 
Pembangunan kepariwisataan dilakukan berdasarkan asas sebagaimana yang tertuang dalam Pasal 2 Undang-undang Republik Indonesia No.10 Tahun 2009 Tentan Kepariwisataan yang diwujudkan melalui pelaksanaan rencana pembangunan kepariwisataan dengan memperhatikan keanekaragaman, keunikan, dan kekhasan budaya dan alam, serta kebutuhan manusia untuk berwisata.

Eksotisme alam pantai menjadi salah satu andalan wisata Kabupaten Lombok Timur (Lotim). Terbilang di sepanjang pantai di kawasan Lotim bagian selatan, berjejer pantai-pantai yang sangat menarik. Hanya saja, pengembangan obyek wisata itu terkendala infrastruktur, terlebih yang menjadi permasalahan adalah belum meratanya listrik dan jalan raya untuk akses ke lokasi belum memadai. Pengembangan pariwisata memiliki karakter aktivitas yang bersifat multisectoral, dalam pelaksanaan pengembangan pariwisata harus terencana secara terpadu dengan pertimbangan-pertimbangan terhadap aspek ekonomi, sosial, budaya, Ingkungan fisik dan politik6.

Secara ekologis, kawasan pesisir sangat kompleks dan mempunyai nilaisumberdaya alam yang tinggi. Kegiatan wisata dan perikananmemberikan kontribusi yang besar dalam peningkatan pendapatan baik masyarakat maupun pemerintah daerah setempat apabila pengelolaannyadilakukan secara terpadu dan berkelanjutan. Salah satu yang diakui adalah pantai Surga Desa Ekas Buana Kecamatan Jerowaru. Kondisi jalan menuju pantai indah dan menawan ini masih terlihat hancur. Dari jalan utama menuju pantai hanya berupa jalan tanah yang belum tersentuh program pengerasan ataupun pengaspalan tanah dari pemerintah.

Landasan Teori

kebijakan publik adalah serangkaian tindakan berupa pilihan untuk melakukan atau tidak melakukan sesuatu dalam rangka mencapai tujuan negara yang merupakan kepentingan publik dengan memperhatikan input yang tersedia,

\footnotetext{
${ }^{6}$ Prayogi P.A. Jurnal Perhotelan dan Pariwisata (Dampak Perkembangan Pariwisata di Objek Wisata Penglipuran), Vol.1 No.1, Agustus 2011.
} 
berdasarkan usulan dari seseorang atau kelompok orang di dalam pemerintahan atau di luar pemerintahan7.

Adapun yang menjadi permasalahan disini adalah kesulitan pemerintah untuk membangun infrastruktur pada kawasan wisata pantai di Lombok Timur. Berdasarkan permasalahan ini maka alternatif apa yang bisa diterapkan supaya pembangunan infrastruktur tetap berjalan tanpa adanya ketegangan antara masyarakat dengan pemerintah setempat?

Metode Yang Digunakan

Adapun metode yang digunakan dalam analisa kebijakan dalam pembangunan berkelanjutan wisata pantai di kawasan Lombok Timur adalah pendekatan bottom-up. Dalam kebijakan yang ditawarkan di atas dapat kita lihat bagaimana supaya ada timbal balik dari kebijakan tersebut yaitu masyarakat mendapatkan manfaat dari pengelolaan tempat wisata dengan membuka akses ekonomi yang lebih baik dan demikian juga dengan pemerintah daerah yaitu dapat menambah pendapatan daerah melalui sektor wisata, khususnya wisata pantai ini.

\section{B. Pembahasan}

1. Alternatif Kebijakan Penyelenggaraan Pembangunan Berkelanjutan Pada Kawasan Wisata Pantai di Lombok Timur.

Adapun alternatif kebijakan yang dapat ditawarkan adalah sebagai berikut:

a. Melakukan Sosialisasi Dengan Masyarakat

Dengan melakukan sosialisasi terhadap masyarakat, memberikan pemahaman tentang dampak dari wisata yang mampu memberikan mereka pendapatan baru dengan adanya kesempatan untuk membuka usaha (misalnya dengan berdagang, dll). Pendekatan pembangunan pariwisata berkelanjutan berbasis masyarakat perlu dipertimbangkan pendekatan ini menempatkan masyarakat sebagai pelaku penting dalam kegiatan pembangunan pariwisata ${ }^{8}$.

${ }^{7}$ Anggraeni R., dkk. Jurnal Administrasi Publik (Evaluasi Kebijakan Publik "Evaluasi Terhadap Pengadaan Anjungan Mandiri Kepegawaian Berdasarkan Perpres No.54 Tahun 2010 di Badan Kepegawaian Daerah Kota Malang). Vol.1, No.1: 2013

8 Masyarakat diberi kesempatan berperan penting dalam pengambilan keputusan yang mempengaruhi dan memberi manfaat terhadap kehidupan dan lingkungan mereka, dalam hal konsep ini mensyaratkan adanya pemberdayaan masyarakat yang sesuai dengan karakteristik dan 
Analisa:

a) Substantive: dalam hal ini, sangat bagus untuk membuka pemahan masyarakat akan dampak dari wisata, khususnya wisata pantai yang ada di daerah Kabupaten Lombok Timur bagian Selatan.

b) Politik: dari segi politik dapat menmberikan dampak pada pemerintah dan masyarakat yaitu adanya kerjasama yang baik antara pemerintah dan warga sekitar.

c) Sosial: dalam hal ini, diskusi sosialisai dan diskusi dengan masyarakat untuk menyatukan pemikiran antara keinginan masyarakat dengan pemerintah, sehingga masyarakat merasa diperhatikan.

d) Teknis: dari segi teknis, tidak terlalu sulit kecuali pihak-pihak yang bersikeras tidak menginginkan adanya pembangunan infrastruktur. Tetapi apabila dilakukan dengan cara musyawarah semuanya akan berjalan lancar.

e) Hukum: dari segi hukumnya akan lebih efektif karena semua keputusan timbul atas dasar keputusan bersama pemerintah dan masyarakat.

f) Ekonomi: secara ekonomi, dengan cara sosialisasi akan lebih efisien dari segi pengeluaran daerah.

g) Ketika kesepakatan antara masyarakat dengan pemerintah telah terjalin maka kita dapat memberikan alternatif kebijakan yang selanjutnya, yaitu:

b. Pembangunan Infrastruktur

Setelah adanya kesepakatan antara pihak masyarakat dengan pemerintah, kita bisa melakukan alternatif yang kedua yaitu membangun infrastruktur pada kawasan wisata pantai, yang menjadi prioritas utama adalah infrastruktur jalan.

Analisa:

a) Substantive: dalam hal ini, alternatif kebijakan pembangunan infrastruktur akan berdampak bagus untuk akses pengunjung ke lokasi wisata.

keunikannya untuk mengembangkan potensi-potensi yang dimilikinya, (Pendekatan Masyarakat Untuk Perencanaan Pariwisata Sangiran: Integrasi Pembangunan Pariwisata Berkelanjutan dan Pelestarian Situs) Jurnal Sangiran No.1 Tahun 2012. 
b) Politik: dari segi politik pemerintah harus lebih dominan dalam pelaksanaan pembangunan infrastruktur.

c) Sosial: dilihat dari segi sosial, masyarakat setempat akan mulai merasakan dampak dari pembangunan infrastruktur dengan akses yang lebih cepat ke lokasi wisata dengan infrastruktur yang lebih bagus di kawasan tempat mereka tinggal.

d) Teknis: dalam hal teknis memang membutuhkan waktu yang sedikit lama dalam pembangunan infrastruktur, tergantung dari anggaran yang disediakan oleh Pemkab Lotim. Apabila pemerintah memberikan dana yang sesuai maka pembangunannya akan cepat selesai.

e) Hukum: dari segi hukum karena adanya kesepakatan antara masyarakat dengan pemerintah, jadi untuk pelaksanaannya tidak ada halangan dari segi hukum.

f) Ekonomi: memang kalau dari segi ekonomi tentunya akan mengeluarkan dana yang tidak sedikit berhubung pantai di kawasan Lombok Timur bagian selatan cukup banyak, sehingga untuk pembangunan infrastruktur cukup banyak membutuhkan dana dari pemerintah.

c. Pengelolaan Daerah Wisata

Apabila infrastruktur sudah terbangun maka langkah selanjutnya adalah memberikan alternatif kebijakan dengan mengelola tempat wisata tentunya tidak lepas dari peranserta masyarakat sekitar. Jadi pemerintah bisa memberikan kesempatan kepada masyarakat untuk ikut bergabung kedalamnya dalam hal pengelolaan wisata. Adapun tujuan mengikutsertakan masyarakat setempat adalah untuk menghindari konflik atau ketegangan antar masyarak dengan pemerintah. Setelah itu pemerintah dapat menarik infestor asing untuk masuk kedalamnya, dengan tujuan bisa menambah penghasilan daerah, seperti yang termaktub dalam pasal 10 Undang-undang No. 10 Tahun 2009 tentang pariwisata yaitu dimana Pemerintah dan Pemerintah Daerah mendorong penanaman modal dalam negeri dan penanaman modal asing di bidang kepariwisataan sesuai dengan rencana induk pembangunan kepariwisataan nasional, provinsi, dan kabupaten/kota. Tidak hanya itu, akan tetapi ini sekaligus bisa menjadi promosi wisata pantai yang ada di kawasan Lombok Timur 
(tepatnya Lombok Timur bagian Selatan) dengan adanya kerjasama dengan investor asing.

Analisa:

a) Substantive: hal ini dirasa sangat bagus apalagi dapat menarik infestor asing masuk kedalamnya.

b) Politik: dari segi politik dapat berdampak baik, dapat menghubungkan pemerintah dengan masyarakat setempat dan kemudian adanya kerjasama dengan infestor asing.

c) Sosial: dari segi sosial maka akan terjadi perubahan sosial pada masyarakat sekitar dengan adanya wisata ini. Yang dimana sebelimnya daerahnya belum dikenal, maka disini diketahui oleh banyak daerah bahkan mancanegara.

d) Teknis: memang dari segi teknis agak sulit mendatangkan investor, tapi satu cara yang bisa dilakukan yaitu membenahi infrastruktur dan promosi wisata maka disinalah infestor akan mulai masuk.

e) Hukum: dari segi hukumnya sangat bagus apabila pengelolaannya mengikutsertakan masyrakat sekita lokasi wisata.

f) Ekonomi: dari sisi ekonomi sangat bagus, selain dapat menambah penghasilan warga sekitar dengan adanya pekerjaan baru bagi mereka, ini juga berdmpak kepada daerah yaitu pendapatan daerah semakin meningkat.

2. Tabel Fisibilitas Alternatif Kebijakan

\begin{tabular}{|c|c|c|c|c|c|c|c|c|}
\hline \multirow{2}{*}{ NO } & \multirow{2}{*}{ ALTERNATIF } & \multicolumn{7}{|c|}{ INDIKATOR (1-10 best) } \\
\cline { 3 - 10 } & & SUBS & TEKNIS & EKONOMI & SOSIAL & POLITIK & HUKUM & TOTAL \\
\hline 1 & SOSIALISASI & 8 & 7 & 8 & 8 & 8 & 9 & 47 \\
\hline 2 & INFRASTRUKTUR & 8 & 6 & 7 & 8 & 9 & 9 & 46 \\
\hline 3 & PENGELOLAAN & 8 & 7 & 9 & 9 & 9 & 9 & 48 \\
\hline
\end{tabular}

Tabel 1: Sekor Alternatif Kebijakan

Keterangan: 1-4 = visibilitas alternatif rendah

$$
\begin{aligned}
& \text { 4-7 = visibilitas alternatif sedang } \\
& \text { 7-10 = visibilitas alternatif tinggi }
\end{aligned}
$$

Ketiga alternatif bisa diterapkan dan sangat bagus untuk tahapan-tahapan pembangunan daerah wisata, terutama daerah-daearah wisata yang di dalamnya ada ketegangan antara pemerintah dengan masyarakat. Akan tetapi alternatif 
yang bagus untuk diterapkan ketika pemerintah dan masyarakat memiliki komitmen yang sama maka langkah yang efektif ketika anggaran dana untuk pembangunan infrastruktur adalah alternative ketiga yaitu pengelolaan yang bagus, apalagi bisa mendatngkan infestor asing untuk masuk di dalamnya.

Dalam tabel fisibilitas alternative kebijakan dari penilaian indikator penilaian yang digunaikan mulai dari 1-4 visibilitas alternatif rendah, 4-7 alternatif sedang, dan 7-10 alternatif tinggi. Adapun alternatif yang memiliki nilai indikator tertinggi adalah alternatif pengelolaan, dalam hal ini yang menjadi alasan mendasar mengapa mengapa pengelolaan menjadi alternative yang memiliki nilai indikator tertinggi? Karena apabila pengelolaan dilakukan dengan baik maka semua persoalan dapat diselasaikan denga baik sesuai keinginan. Tentunya semua ini bisa berjalan apabila pemerintah bisa bekerjasama dengan masyarakat. Hal yang paling penting adalah bagaimana pemeintah mampu untuk meyakinkan masyarakat bahwa dengan adanya wisata pantai ini berdanpak positif bagi masyarakat untuk mendongkar pertumbuhan ekonomi masyarakat dan menambah pendapatan daerah dari sektor pariwisata.

Dan inti dari semua tawaran kebijakan di atas adalah bagaimana membudayakan dan memberdayakan masyarakat sekitar dengan melakukan pendekatan-pendekatan kultural baik berbentuk sosioligi, antropologis dan lainlain. Adapun pemberdayaan itu mengandung dua arti, pertama memindahkan kekuasaan dari pemerintah kemasyarakat maksudnya tidak mesti sepenuhnya dilimpahkan kepada masyarakat tetapi kontrol dari pemerintah tetap ada supaya masyarakat merasa memiliki. Kedua, memotifasi masyarakat sehingga produktifitasnya meningkat, sehingga masyarakat mampu meningkatkan UMKM (Usaha Mikro, Kecil, dan Menengah).

3. Pengembangan Alternatif Kebijakan

a) Goals

Dalam hal ini adapun tujuan utama yang ingin dicapai adalah untuk memajukan wisata Lombok, khususnya wisata pantai kawasan Lombok Timur (bagian Selatan). Dan menghasilkan dampak yang baik bagi daerah tentunya dengan tujuan memajukan daerah dan memberdayakan 
masyarakat sekitar kawasan wisata khususnya dan masyarakat Lombok secara luas.

b) Target Groups

Target disini yaitu masyarakat dan pemerintah, tentunya dengan pengembangan potensi sumber daya alam yang dimiliki oleh pulau Lombok guna untuk mengembangkan daerah, dan tentunya sesuai dengan tujuan dari kepariwisataan itu sendiri yaitu: meningkatkan pertumbuhan ekonomi, meningkatkan kesejahteraan rakyat, menghapus kemiskinan, mengatasi pengangguran, melestarikan alam, lingkungan dan sumber daya, kemudian memajukan kebudayaan, mengangkat citra bangsa, memupuk rasa cinta tanah air, memperkukuh jati diri dan kesatuan bangsa, dan mempererat persahabatan antarbangsa.

3) Agen

Agen disini adalah masyarakat dan para perwakilan dari pemerintah yang berfungsi untuk mengurus kelangsungan pembangunan maupun pengelolaan daerah wisata pantai di kawasan Lombok Timur bagian Selatan.

4) Struktur implementasi

Di sini yang memiliki peran penting dan tanggung jawab yang besar adalah pemerintah dan tokoh masyarakat daerah setempat.

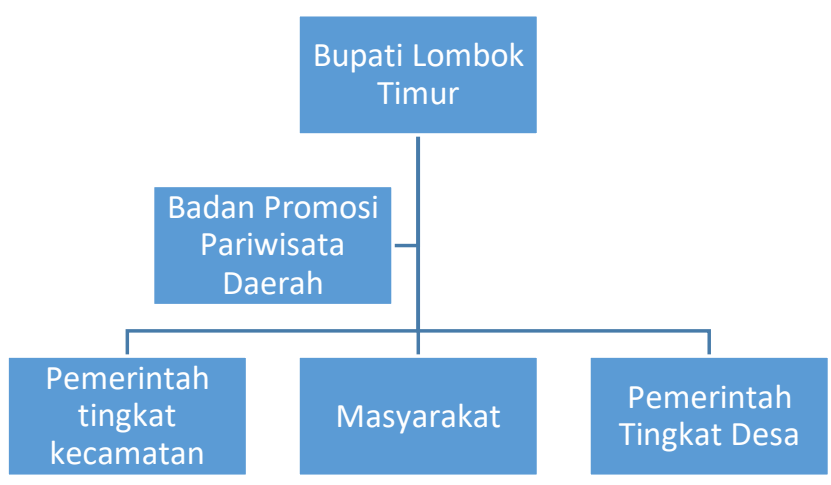

Diagram 1: Struktur Implementasi Kebijakan

5) Assumptions

Apabila semua alternatif kebijakan ini dijalakan sesuai dengan prosedur hukum maka besar harapan tidak terjadi benturan antara masyarakat dengan pemerintah, malah sebaliknya masyarakat mendukung program pemerintah apabila tidak bertentangan dengan norma-norma adat yang 
berlaku. Tentunya pemerintah harus bisa ambil posisi dengan mempertimbangkan Norma adat dan kesepakan bersama.

6) Rules

Adapun kebijakan tersubut dipandang sebagai kesepakatan bersama antara pemerintah daerah dengan masyarakat yang dilatar belakangi sesuai dengan Kultur masyarakat dan dapat memberikan dampak yang positif bagi daerah dan masyarakat tentunya. Kemudian pemerintah menjalankan fungsi pengasannya dan masyarakat mendukung program pemerintah.

4. Policy Implementation

1. Analisis Konten dan Konteks Kebijakan

a. Konten Kebijakan:

1) Interest Affected

Dalam penerapan kebijakan ini sangat mudah untuh mengakses segala hal yang berkaitan dengan perkembangan pariwisata karena dengan keterlibatan masyarakat didalamnya memungkinkan akan menumbuhkan rasa kepemilikan oleh masyarakat sehingga mereka merasa berkewajiban untuk menjaga dan mengawasi perkembangan wisata (kuhusnya wisata pantai).

2) Type of Benefits

Adapun dampak yang bisa terlihat dari penerapan kebijakan ini adalah dapat terlihat bagaimana menciptakan masyarakat yang mandiri dengan mengembangkan usaha-usaha mikro di kawasan wisata, sehingga mampu mendongkrak laju ekonomi masyarakat akan meningkat sehingga pengelolaan akan semakin mudah dijalakan karena apabila masyarakat merasakan dampak positif dari pembangunan infrastruktur wisata pantai, tidak hanya itu anggaran pendapatan daerah melalui sektor wisata juga akan bertambah.

3) Extent of Change Envisioned

Kebijakan ini di implentasikan di daerah wisata yang menjadi sasaran adalah masyarakat untuk ikut serta mengawasi jalannya kebijakan, tetapi pemerintah tidak serta merta 
melimpahkannya kepada masyarakat, jadi pemerintah harus tetapa menjalankan fungsinya pengawasannya supaya ada kerjasama antara pemerintah dan masyarakat yang berakibat masyarakat akan mendukung pemerintah untuk mengembangkan daerah wisata yang memiliki daya Tarik terhadap wisatawan.

4) Site of Decision Making

Badan Promosi Pariwisata Daerah sebagai agen kebijakan yang berhubugan dengan masyarakat memberikan ruang yang terbuka untuk masyarakat dalam penyelesaian permasalahpermasalah yang terkait dengan kebijakan atau permasalah dalam masarakat sehingga permasalahan tersebut bisa diselesaikan secara musyawarah. Jadi ketika masyarakan diberikan kepercayaan oleh pemerintah daerah maka masyarakan merasa tidak tertekan dengan kebijakan-kebijakan yang ditetapkan oleh pemerintah, terkecuali hal-hal sifatnya structural dan lebih keteknis pemerintah harus lebih dominan memberikan arahan kepada masyarakat.

5) Program Implementors

Implementasi program ini disusun secara struktur yang melibatkan: Bupati dengan melimpahkan wewenang kepada Badan Promosi Pariwisata Daerah (BPPD) kemudian bekerjasama dengan pemerintah tingkat kecamatan, pemerintah Desa serta musyawarah dengan masyarakat untuk menyusun program pembangunan infra struktur wisata pantai sehingga tersusun tim pelaksana dan tim pengawas pelaksanaan yang dibentuk berdasarkan kesepakan bersama. Implementasi kebijakan merupakan suatu tahpan yang diadopsi dilaksanakan oleh unit-unit administrative tertentu dengan memobilisasikan dana dan sumber daya yang ada ${ }^{9}$.

${ }^{9}$ Mouw E. Jurnal UNIERA (Implementasi Kebijakan Program Pestival Teluk Jailolo di Kabupaten Halmahera Barat), Vol.3 No.1; ISSN 2086-0404, februari 2014. 
6) Resources Commited

Pengadaan alat pembangunan ifrastruktur menggunakan dana APBD yang dianggarkan setiap tahunnya untuk pengembangan daerah. Selain itu ditunjang oleh sumberdaya yang ada dalam masyarakat untuk terus berupaya mengembangkan potensi yang ada sehingga akan memperlancar pelaksanaan pembangunan infrastruktur.

2. Konteks Kebijakan

1) Power, Interests, and Strategies Actors Involved

Stakeholder/ Pemangku kepentingan adalah Bupati Lombok Timur yang memberikan wewenang kepada Badan Promosi Pariwisata Daerah sebagai perancang dan pembenduk kebijakan beserata pemerintah tingkat Kecamatan, pemerintah Desa dan untuk ranah publik adanya peran Masyarakat di dalamnya. Dalam hal ini kemudian DPRD menjalankan pungsingsinya untuk mengawasi pelaksanaan pembangunan infrastruktur wisata yang sekaligus menentukan jumlah anggaran yang akan dikeluarkan oleh pemerintah dalam rangka membangun infrastrukrut wisata. Dan kemudian untuk pelaksanaan dan pengadaan barang pemerintah memberikan kepada tender pemenang, ketika pemenang tender ditentukan oleh pemerintah maka pemerintahlah yang harus lebih banyak mengontrol jalannya pelaksanaan pembangunan infrastruktur wisata, tetapi apa bila pelaksanaannya pembangunan di kerjakan oleh swasta maka swasta harus bertanggung jawab sesuai dengan kesepakan untuk menyelesaikan kontrak pelaksanaan pembangunan infrastruktur wisata ini.

2) Institutions and Regime Characteristic

Dilihat dari segi birokrasi pemerintahan Kabupaten Lombok Timur lebih bersifat demokratis dan terbuka sehingga memudahkan akses antara hubungan pemerintah dengan masyarakat, dengan tujuan supaya masyarakat bisa memberikan informasi dan kontribusi yang besar terhadap 
pemerintah untuk mengembangkan daerah dengan mempertahankan kearifan lokal baik budaya dan tradisi yang sudah hidup dalam masyarakat. Institusi pemerintahan berfungsi menciptakan lingkungan politik dan hokum yang kondusif, sektor swasta menyediakan lapangan pekerjaan dan menciptakan pendapatan, sedangkan masyarakat (society) berperan positif dalam interaksi sosial, ekonomi dan politik termasuk mengajak kelompok-kelompok dalam masyarakat untuk berpartisipasi dalam aktifitas produktif dan pemberdayaan masyarakat ${ }^{10}$.

3) Compliance and Responsiveness

Dari segi birokrasi, dengan ketegasan yang ditunjukkan oleh Bupati Lombok Timur akan berdampak terhadap birokrasi dalam pelaksanaan kebijakan akan berjalan dengan baik. Selain itu antosiasi masyarakat yang mendukung pemerintah untuk mempercepat pembangunan infrastruktur yang mulai sadar dengan dilakukannya sosialisasi akan danfak positif dari pengembangan wisata.

2. Faktor-Faktor Yang Dipersiapkan (Enabling Conditions)

a. Pendekatan Sosial

Pendekatan sosial dilakukan dengan melakukan pendekatan dan sosialisasi, hal ini perlu dilakukan untuk memberikan pemahan tentang pelaksanaa pembangunan infrastrukitur wisata, baik itu di tingakat pemerintah maupun msyarakat sehinga mempermudah untuk mendapatkan dukungan dalam pelaksanaannya.

b. Komitmen Agen Pelaksana

Komitmen dari pelaksana adalah dasar dari kelancaran program yang direncanakan, sehingga ketika agen memiliki komitmen yang tinggi maka diyakini bahwa pelaksanaan kebijakan akan berjalan sesuai dengan rencana pelaksanaann yang sudah ditentukan.

${ }^{10}$ Suratmi, Santosa S., Manajemen Bisnis Syariah (Strategi Pemerintah Kota Surakarta dalam Melakukan City Branding Sebagai Kota Budaya). No. 2/Th.VI/ Februari 2013. 


\section{Policy Evaluation}

Pembangunan berkelanjutan pada sektor pariwisata mendapatkan perhatian yang cukup luas dari berbagai kalangan, pembangunan pariwisata berkelanjutan dapat diartikan sebagai aktivitas pariwisata yang dapat memenuhi kebutuhan semua pihak saat ini. Untuk kemajuan pariwisata maka diperlukan sistim pemasaran yang baik, strategi pemasaran destinasi wisata berkelanjutan (sustainable tourismdestination marking strategy): (1) tahap identifikasi (identification), (2) tahap formulasi strategi (formulation), (3) tahap implementasi dari strategi dimaksud (implementation), (4) tahap monitoring dan evaluasi terhadap hasil-hasil yang dicapai (monitoring and evaluation), (Suradnya: 2011). Inti dari pembangun pariwisata berkelanjutan adalah system monitoring dan evaluasi.

\section{Monitoring}

Untuk kelancara program monitoring dilakukan setiap bulannya, ini bertujuan untuk terus melihat perkembangan dari pelaksanaan kebijakan yang diterapkan sehingga dapat mengukur perkembangan yang dihasilakan oleh kebijakan terhadapat kemajuan daerah. Monitoring adalah proses pengumpulan dan analisis informasi (berdasarkan indikator yg ditetapkan) secara sistematis dan kontinyu tentang kegiatan program/proyek sehingga dapat dilakukan tindakan koreksi untuk penyempurnaan program/proyek itu selanjutnya.

Monitoring dapat didefinisikan sebagai fungsi manajemen untuk membimbing dalam arah yang dituju dan untuk memeriksa kinerja terhadap pra-rencana ditentukan. Monitoring adalah kegiatan yang dilakukan untuk mengecek penampilan dari aktivitas yang sedang dikerjakan. Atau dapat juga dikatakan monitoring yaitu proses pengumpulan dan analisis informasi (berdasarkan indikator yang ditetapkan) secara sistematis dan kontinu tentang kegiatan program atau proyek sehingga dapat dilakukan tindakan koreksi untuk penyempurnaan program atau proyek itu selanjutnya ${ }^{11}$.

\section{Evaluasi}

11 http://pramitasarah.wordpress.com/2010/11/28/monitoring, di akses pada tgl 17/12/2014 
Evaluasi kebijakan dalam perspektif alur proses/siklus kebijakan publik, menempati posisi terakhir setelah implementasi kebijakan, sehingga sudah sewajarnya jika kebijakan publik yang telah dibuat dan dilaksanakan lalu dievaluasi. Dari evaluasi akan diketahui keberhasilan atau kegagalan sebuah kebijakan, sehingga secara normatif akan diperoleh rekomendasi apakah kebijakan dapat dilanjutkan; atau perlu perbaikan sebelum dilanjutkan, atau bahkan harus dihentikan. Evaluasi juga menilai keterkaitan antara teori (kebijakan) dengan prakteknya (implementasi) dalam bentuk dampak kebijakan, apakah dampak tersebut sesuai dengan yang diperkirakan atau tidak. Dari hasil evaluasi pula kita dapat menilai apakah sebuah kebijakan/program memberikan manfaat atau tidak bagi masyarakat yang dituju. Secara normatif fungsi evaluasi sangat dibutuhkan sebagai bentuk pertanggung-jawaban publik, terlebih di masa masyarakat yang makin kritis menilai kinerja pemerintah. ${ }^{12}$

\section{Simpulan}

Dalam perencanaan kebijakan hingga implementasi kebijakan di lapangan hendaknya mengikutsertakan masyarakat di dalamnya, mulai dari pengambilan keputusan kebijakan. Karena program yang diterapkan tidak akan berjalan dengan baik apabila nilai-nilai yang hidup dalam masyarakat, kultur, budaya tidak diperhatikan dalam pembentukan kebijakan. Kemudian system kontrol dari pemerintah harus berjalan baik dari segi pengawasan hingga pengelolaan objek wisata guna menjaga kelangsungan pengembangan wisata terutama wisata pantai yang ada di kawasan Lombok Timur khususnya bagian Selatan. Sehingga dengan diterapkannya kebijakan yang baik maka keberlangsungan pengelolaan berkelanjutan pariwisata akan lebih mudah untuk dilakukan.

\section{Daftar Pustaka}

\section{Undang-Undang \& Peraturan daerah:}

- Undang-Undang Dasar 1945

- Undang-Undang No 10 Tahun 2009 Tentang Kepariwisataan

- Peraturan Bupati Lombok Timur Nomor 3 Tahun 2013 Tentang Tata Kerja, Persyaratan, Serta Tata Cara Pengangkatan Dan Pemberhentian Unsur Penentu Kebijakan Badan Promosi Pariwisata Daerah Kabupaten Lombok Timur.

\footnotetext{
12 http://rochyati-w-t-fisip.web.unair.ac.id, di akses pada tgl 17/12/2014
} 
Novia Suhastini

Jurnal:

Andayani S, dkk. Jurnal Rekayasa Sipil (Pengembangan Kawasan Wisata Balekambang Kabupaten Malang), Volume 6, No. 2-2012 ISSN 19785658.

Anggraeni R., dkk. Jurnal Administrasi Publik (Evaluasi Kebijakan Publik "Evaluasi Terhadap Pengadaan Anjungan Mandiri Kepegawaian Berdasarkan Perpres No.54 Tahun 2010 di Badan Kepegawaian Daerah Kota Malang). Vol.1, No.1: 2013

Irianto. Jurnal Bisnis dan Kewirausahaan (Dampak Pariwisata Terhadap Kehidupan Sosial dan Ekonomi Masyarakat di Gili Trawanagna Kecamatan Pemenang Kabupaten Lombok Utara). Vol.7 No.3 November 2011.

Mouw E. Jurnal UNIERA (Implementasi Kebijakan Program Pestival Teluk Jailolo di Kabupaten Halmahera Barat), Vol.3 No.1; ISSN 2086-0404, februari 2014.

Panglipur R.S (Pendekatan Masyarakat Untuk Perencanaan Pariwisata Sangiran: Integrasi Pembangunan Pariwisata Berkelanjutan dan Pelestarian Situs) Jurnal Sangiran No.1 Tahun 2012.

Parma, I.P.G, (Kajian Perencanaan Penataan Daya Tarik Wisata Pelabuhan Buleleng), vol.10, No.2 Desember 2011 ISSN 1412-8683.

Prasetyo P, Jurnal Ilmu Pemerintahan, (Strategi Dinas Kebudayaan Pemuda dan Olahraga Dalam Pengembangan Potensi Objek Wisata Kota Tarakan), 2013, 1 (1): 151-164.

Prayogi P.A. Jurnal Perhotelan dan Pariwisata (Dampak Perkembangan Pariwisata di Objek Wisata Penglipuran), Vol.1 No.1, Agustus 2011.

Suradnya I.M, JUrnal IImiah Manajemen \& Akuntansi STIE Triatma Mulya (Strategi pemasaran Destinasi Pariwisata Berkelanjutan), Vol 16, No.2 Edisi Desember 2011.

Suratmi, Santosa S., Manajemen Bisnis Syariah (Strategi Pemerintah Kota Surakarta dalam Melakukan City Branding Sebagai Kota Budaya). No. 2/Th.VI/ Februari 2013.

Wiryawan I.W.G. Jurnal Advokasi (Paradoks Kebijakan Industrialisasi Pariwisata Dengan Perlindungan Terhadap Upah Pekerja di Bidang Kepariwisataan di Provinsi Bali). Vol.3 No.1 April 2013. 